\title{
INSECTICIDE SELECTIVITY FOR Doru lineare (DERMAPTERA: FORFICULIDAE)
}

\author{
CRISTIANE DOS SANTOS STECCA ${ }^{1}$, AMARILDO PASINI ${ }^{1}$, ADENEY DE FREITAS BUENO ${ }^{2}$, \\ MARLON DIAS DENEZ ${ }^{1}$, DEBORA MELLO DA SILVA ${ }^{1}$ and MAICO ANDRE MORAES \\ MANTOVANI $^{3}$
}

${ }^{1}$ State University of Londrina, UEL, Londrina, PR, Brazil

${ }^{2}$ Embrapa Soybean, Londrina, PR, Brazil

${ }^{3}$ Centro Universitário Filadélfia, Londrina, PR, Brazil

$\overline{\text { Revista Brasileira de Milho e Sorgo, v.13, n.1, p. 107-115, } 2014}$

\begin{abstract}
This study aimed at assessing selectivity of insecticides to adults of Doru lineare. The tests were performed under controlled environmental conditions. Insecticides tested ( $\mathrm{g}$ a.i. ha $\left.{ }^{-1}\right)$ were: flubendiamide (72); chlorantraniliprole (30); chlorantraniliprole (15) + lambda-cyhalothrin (7.5); lambda-cyhalothrin (7.5); chlorpyriphos (480); and control (distilled water). Treatments were sprayed over arenas made up with glass plates (area $169 \mathrm{~cm}^{2}$ ), imprisoning the insect with PVC rings. The top of the rings was protected with a fine fabric (tulle) where adult insects were sprayed with insecticides using a Potter Tower. Insect survival was assessed at 24, 48, 72, 96, and $120 \mathrm{~h}$ after exposing adults to the treatments. Flubendiamide and chlorantraniliprole were classified as harmless (class 1) to $D$. lineare and therefore apropriated to be used in Integrated Pest Management (IPM) programs since they can be sprayed preserving natural biological control. Chlorpyriphos, lambda-cyhalothrin and the mixture of chlorantraniliprole + lambda-cyhalothrin were harmful (class 4), moderately harmful (class 3 ), and slightly harmful (class 2 ), respectively. Non-selective products should also be tested in semi-field and field conditions to evaluate its persistence. Whenever possible, noxious and persistent insecticides should be replaced for more selective ones.
\end{abstract}

Key words: Dyamide; Pyretroid; Natural Enemy; predator, toxicity.

\section{SELETIVIDADE DE INSETICIDAS A Doru lineare (DERMAPTERA: FORFICULIDAE)}

RESUMO - Este trabalho avaliou a seletividade de inseticidas a adultos de Doru lineare. Os testes foram conduzidos em condições controladas. Os inseticidas testados (g i.a. ha ${ }^{-1}$ ) foram: flubendiamida (72); clorantraniliprole (30); clorantraniliprole (15) + lambda-cialotrina (7,5); lambda-cialotrina (7,5); clorpirifós (480); e controle (água destilada). Os tratamentos foram aplicados em arenas compostas de placas de vidro (área $169 \mathrm{~cm}^{2}$ ), aprisionando o inseto com anéis de PVC. A extremidade superior do anel foi protegida com tecido fino (tule), onde os adultos receberam aplicação tópica dos inseticidas através de Torre de Potter. A sobrevivência dos insetos foi avaliada 24, 48, 72, 96 e 120 horas após a exposição dos adultos aos tratamentos. Flubendiamida e clorantraniliprole foram classificados como inócuo (classe 1) a D. lineare e, portanto, são apropriados para uso em programas de Manejo Integrado de Pragas (MIP) porque podem ser aplicados preservando o controle biológico natural. Clorpirifós, lambda-cialotrina e clorantraniprole + lambdacialotrina foram nocivo (classe 4), moderadamente nocivo (classe 3 ) e levemente nociva (classe 2), respectivamente. Produtos não seletivos precisam ser também testados em semi-campo e campo para avaliar a persistência. Inseticidas nocivos e persistentes devem, sempre que possível, ser substituídos por outros mais seletivos.

Palavras-chave: Diamida; Piretróide; Inimigo Natural; predador; toxicidade. 
Corn (Zea mays) is one of the most important crops around the world and Brazil is the third bigger corn global producer (Conab, 2012). However, one of the factors that may endanger such good yield, besides production quality, is the outbreaks of pest-insects, which can attack plants during all its development stages; reducing yields. Among these pests, the fall armyworm, Spodoptera frugiperda (J. E. Smith) (Lepidoptera: Noctuidae), should be emphasized; once it is considered the most prejudicial corn pest, and able to reduce corn productivity up to $54 \%$, or even more (Figueiredo et al., 2006).

Not only to minimize the damage of this pest but also of other pest species, the action of biological control agents is of great importance, once these beneficial insects can control several pest species that cause damages to corn plants. Among these natural enemies, the earwigs, Doru lineare Eschscholtz (Dermaptera: Forficulidae), have stand out as a highly active predator, feeding on several preys (polyphagia), particularly on eggs and small immature instars of pests from the orders Lepidoptera, Hemiptera, Coleoptera, and Diptera (Costa et al., 2007). Cruz (1995) reported that $D$. luteipes nymphs and adults, may daily consume 10 and 20 secondinstar caterpillars of $S$. frugiperda, respectively. This shows the importance of this group of predators to corn integrated pest management (Corn-IPM).

Despite of the importance of this natural enemy, the use of chemical insecticides is still needed for pest control, aiming at guaranteeing high yield of the crop in a wide scale. Therefore, taking the necessity of chemical control into consideration, it must be used in a harmonious and compatible way with beneficial insects aiming at preserving the natural biological control. Studies have been conducted on the selectivity of pesticides used in Corn-IPM
(Redoan et al., 2012; Zotti et al., 2010a; Zotti et al., 2010b; Picanço et al., 2003). However, there is still a great shortage of further studies in this area, chiefly considering the species $D$. lineare and the new insecticide compounds more recently recommended to corn pest management.

In addition, it is important to emphasize that a significant part of the biological unbalance occurring in agricultural systems is due to the inadequate use of non-selective pesticides to beneficial arthropods. Therefore, the preservation of natural enemies of agricultural pests has become one of the most important practice in IPM. Thus, when pesticides are used as part of management, these products should not only be efficient against pests, but also be as harmless as possible to beneficial organisms (Mohaghegh et al., 2000). Considering the need of using more selective products for preserving beneficial insects, this study had the objective of assessing the selectivity of different insecticides on adults of the predator $D$. lineare.

The test was conducted as described by Sauphanor et al. (1992) in accordance with the norms of the IOBC/WPRS Working Group 'Pesticides and Beneficial Organisms' (Hassan et al., 2000; Bueno \& Freitas, 2004). Nymphs of linear earwig were field collected in a corn crop without the use of insecticides at the School Farm of the State University of Londrina (UEL), State of Paraná, Brazil. The insects were taken to the laboratory and identified as $D$. lineare. In the laboratory the insects were fed with $S$. frugiperda larvae until they reach the adult stage when they were used in the trials. For the trials D. lineare adults of until 2-day old were used what guaranteed insects of the same age. The experiment was carried out in the laboratory, under controlled environmental conditions $\left[25 \pm 1{ }^{\circ} \mathrm{C} ; 70 \pm 10 \% \mathrm{UR}\right.$; 
and photoperiod of 12/12 h (Light/Dark)] testing the higher registered insecticide dose. It was used a completely randomized experimental design with six treatments and five replications, composed by 10 insects each replication (50 insects per treatment). The trademarks and dosages of active ingredients were (g a.i. ha $\left.{ }^{-1}\right)$ : Belt $\AA$, flubendiamide (72); 2) Prêmio $\AA$, chlorantraniliprole (30); 3) Ampligo ${ }^{\circledR}$, chlorantraniliprole (15) + lambda-cyhalothrin (7.5), ; and 4) Karate Zeon $250 \mathrm{CS} \AA$, lambda-cyhalothrin (7.5). By following the protocols standardized by the IOBC/WPRS, two standard treatments were added (Manzoni et al., 2007): one negative control (distilled water) and one positive control (chlorpyriphos 480 g a.i. ha- $\left.{ }^{-1}\right)$.

Treatments were sprayed over arenas made up with a glass plate (area $169 \mathrm{~cm}^{2}$ ), imprisoning the insect with a PVC ring with $3 \mathrm{~cm}$ tall and 7.5 $\mathrm{cm}$ in diameter. Adults of the insect received topical application of the insecticides from a Potter Tower regulated to a pressure of $1.5 \mathrm{kgf} \mathrm{cm}^{-2}$ similar to the procedures adopted by Bueno \& Freitas (2004). The rings were protected on the top with a fine cloth (tulle) and their walls were covered with fluon to reduce adherence. Each replicate was sprayed with $1.75 \pm 0.25 \mathrm{mg} \mathrm{cm} \mathrm{cm}^{2}$ of product solution, according to standards of IOBC/WPRS (Hassan et al., 2000; Manzoni et al., 2007).

The insect survival was assessed at 24, 48, 72, 96, and $120 \mathrm{~h}$ after exposing the earwigs to the different treatments. During all the assessment period, the insects were daily fed with $S$. frugiperda eggs from laboratory colony. The effect of each insecticide on the earwig was obtained based on the modified formula of Overmeer \& Van Zon (1985) and calculated as follows: $E=100 \%-(100 \%-$ $\mathrm{M} \%$ ), in which;
$\mathrm{E}=$ Total effect of insecticide (\%).

$\mathrm{M} \%=$ Mortality corrected by control mortality (Abbott, 1925).

The products were classified in accordance with the IOBC/WPRS system in which the impact on the population tested is assessed as class 1 , harmless $(\mathrm{E}<30 \%)$; class 2, slightly harmful $(30 \%$ $\leq \mathrm{E} \leq 79 \%)$; class 3, moderately harmful $(80 \% \leq \mathrm{E} \leq$ 99\%); and class 4, harmful ( $\mathrm{E}>99 \%$ ) (Manzoni et al., 2007). In addition, survival results were submitted to evaluation of the assumptions of normality of residues (Shapiro \& Wilk, 1965), homogeneity of variance of treatments (Burr \& Foster, 1972), and additivity of the model, to allow for analysis of variance (Anova). Means were then compared by the Tukey test at 5\% probability (SAS Institute, 2001).

The chlorpyrifos (480 g i.a. ha $\left.{ }^{-1}\right)$ was classified as harmful (class 4 ) to adults of $D$. lineare by killing $100 \%$ of individuals within 24 -h time frame (Table 1). This result was already expected since this treatment has been previously classified as harmful to different beneficial arthropods and therefore used as positive control treatment (non-selective pesticide) (Carmo et al., 2010; Campos et al., 2011). As already mentioned, the toxicity of chlorpyrifos on predators of genus Doru, in addition to other various natural enemies, has already been reported in the literature by some other authors (Ferreira et al., 2006; Case et al., 2010; Zotti et al., 2010a; Zotti et al., 2010b). This insecticide has a wide spectrum of action and is highly toxic, as much under laboratory as field conditions (YU, 1987). The low selectivity of chlorpyrifos can be explained by its mode of action; once for being an insecticide that acts on the nervous system, its action is usually common to all insect species. This insecticide binds itself to the acetyl-cholinesterase enzyme, thus inhibiting the transmission of nerve 
impulses of the insects, in a manner that, with the accumulation of acetylcholine in the synaptic cleft, occurs the hyper-excitability of the central nervous system, causing paralysis and death of the infected insect (Komeza et al., 2001).

Similarly to chlorpyrifos, lambdacyhalothrin (7.5 g a.i. ha-1) has also exerted deleterious effects on adults of $D$. lineare. However, this insecticide presented statistically significant difference for the survival of adult predators in the treatment with chlorpyrifos until 72 hours after application (HAA). Differently, in 96 and 120 HAA, statistical differences on survival of earwig did not occur; nevertheless, lambda-cyhalothrin was classified as moderately harmful (class 3) (Table 1). Different results were reported by both Zotti et al. (2010a), who have verified death of $100 \%$ of $D$. lineare nymphs $24 \mathrm{~h}$ after application of this insecticide and Zotti et al. (2010b) who reported $77 \%$ mortality for $D$. lineare adults 96 HAA (product classified as slighgtly harmful - class 2) and 100\% mortality 168 HAA (product classified as harmful - class 4). These differences are probably due to the different insect development stages used and different timing of evaluation after insecticide exposure. It is important to point out that adults have a cuticle thicker and rich in lipids, thus providing increased metabolic activity (Guedes et al., 1992), what gives a greater selectivity to the product in relation to nymphs that are the instar more sensitive of the insect to the action of pesticides (Bacci et al., 2001).

The pyrethroids, the chemical group of lambda-cyhalothrin, are neurotoxic insecticides that act in the nerve system of insect, paralyzing and killing it rapidly (Bueno et al., 2008). Pesticides of this group are generally sorted as products less selective to natural enemies (Carvalho et al., 1999). Bueno et al. (2008) and Manzoni et al. (2007) have also shown that some pyrethroids have harmful effect on the egg parasitoids Trichogramma pretiosum and T. atopovilia (Hymenoptera: Trichogrammatidae), respectively. Some pyrethroids, however, can be differently classified depending upon the insecticide rate tested or development stage of the insect. Bueno et al. (2008) observed that bifenthrin ( $5 \mathrm{~g}$ a.i. ha $\left.{ }^{-1}\right)$ and gama-cyhalothrin (3.75 g a.i. ha $\left.{ }^{-1}\right)$ were classified as slightly harmful (class 2) and harmless (class 1) to the pupae of T. pretiosum, respectively. The selectivity or non-selectivity of pyrethroids is usually associated with the tested rate as well as penetration of molecules of these products in the cuticle of the natural enemy, rate of metabolism of these molecules, induced by microsomal oxidases and esterases. This effect may be higher or lower in beneficial arthropods compared to pest species; thus, generating a lower toxicity of the pesticides on natural enemies than in their prey (Yu, 1987; Guedes et al., 1992).

As in this study, the insecticides chlorpyrifos and lambda-cyhalothrin were not selective to $D$. lineare, their use is not appropriated in Corn-IPM. Therefore, whenever possible, these products should be avoided or replaced by more selective insecticides. Differently, the survival observed in the treatments with flubendiamide and chlorantraniliprole was higher than $90 \%$, not presenting statistical differences in relation to the negative control (distilled water). Therefore, both these products were classified as harmless (class 1) to D. lineare adults (Table 1) and are apropriated to be used in Integrated Pest Management (IPM) programs since they can be sprayed preserving natural biological control.

Flubendiamide is the first member of a new chemical class, the phthalic acid diamides, with a 
novel chemical structure. The structure consists of three parts; a heptafluoroisopropyl group in the anilide moiety, a sulfonylalkyl group in the aliphatic amide moiety, and an iodine atom at the 3-position of the phthalic acid moiety. Chlorantraniliprole is the ISO approved common name for 3-bromo$\mathrm{N}$-[4-chloro-2-methyl-6-(methylcarbamoyl) phenyl]-1-(3-chloropyridin-2-yl)-1H-pyrazole-5carboxamide). Both compounds are insecticides belonging to the group of diamides that act on the ryanodine receptors (RyRs), a distinct class of channels that controls the release of calcium from the intracellular storages. These RyRs receptors are responsible by muscular flexibility. Therefore, when the molecule links itself to the RyRs receptor, it promotes opening of calcium channels and the uncontrolled release of the internal medium $(\mathrm{Ca}$ deposit) to the external medium (cellular cytoplasm)

TABLE 1. Effect of different insecticides on adults of Doru lineare, assessed in different hours after application (HAA) and their toxicity classification, according to the standards established by the International Organization for Biological Control (IOBC/WPRS). ${ }^{1}$

\begin{tabular}{|c|c|c|c|c|c|c|c|}
\hline \multirow{2}{*}{$\begin{array}{c}\text { Treatments } \\
\text { g a.i. ha }\end{array}$} & \multicolumn{5}{|c|}{ Live insects HAA $(\text { Mean } \pm S E)^{1}$} & \multirow{2}{*}{$\mathrm{E} \%{ }^{2}$} & \multirow{2}{*}{$\mathrm{C}^{3}$} \\
\hline & 24 HAA & $48 \mathrm{HAA}$ & 72 HAA & 96 HAA & $120 \mathrm{HAA}$ & & \\
\hline Control & $10.0 \pm 0.0 \mathrm{a}$ & $10.0 \pm 0.0 \mathrm{a}$ & $10.0 \pm 0.0 \mathrm{a}$ & $9.6 \pm 0.2 \mathrm{a}$ & $8.8 \pm 0.2 \mathrm{a}$ & - & - \\
\hline Flubendiamide 72 & $10.0 \pm 0.0 \mathrm{a}$ & $10.0 \pm 0.0 \mathrm{a}$ & $10.0 \pm 0.0 \mathrm{a}$ & $9.3 \pm 0.5 \mathrm{a}$ & $8.5 \pm 0.6 \mathrm{a}$ & 3 & 1 \\
\hline Chlorantraniliprole 30 & $10.0 \pm 0.0 \mathrm{a}$ & $10.0 \pm 0.0 \mathrm{a}$ & $10.0 \pm 0.0 \mathrm{a}$ & $8.8 \pm 0.3 \mathrm{ab}$ & $8.0 \pm 0.4 \mathrm{ab}$ & 9 & 1 \\
\hline $\begin{array}{l}\text { Chlorantraniliprole } 15+ \\
\text { lambda-cyhalothrin } 7.5\end{array}$ & $9.6 \pm 0.2 \mathrm{a}$ & $9.4 \pm 0.4 \mathrm{a}$ & $9.4 \pm 0.4 \mathrm{a}$ & $7.0 \pm 0.7 \mathrm{~b}$ & $6.2 \pm 0.7 \mathrm{~b}$ & 30 & 2 \\
\hline Lambda-cyhalothrin 7.5 & $8.6 \pm 0.4 b$ & $6.0 \pm 0.8 \mathrm{~b}$ & $5.4 \pm 0.6 b$ & $1.2 \pm 0.7 \mathrm{c}$ & $0.8 \pm 0.4 \mathrm{c}$ & 91 & 3 \\
\hline Chlorpyrifos 480 & $0.0 \pm 0.0 \mathrm{c}$ & $0.0 \pm 0.0 \mathrm{c}$ & $0.0 \pm 0.0 \mathrm{c}$ & $0.0 \pm 0.0 \mathrm{c}$ & $0.0 \pm 0.0 \mathrm{c}$ & 100 & 4 \\
\hline C.V. $(\%)$ & 5.32 & 11.96 & 9,44 & 18.72 & 19.05 & - & - \\
\hline $\mathrm{F}$ & 430.44 & 100.15 & 169,79 & 75.19 & 77.45 & - & - \\
\hline $\mathrm{p}$ & $<0.0001$ & $<0.0001$ & $<0,0001$ & $<0.0001$ & $<0.0001$ & - & - \\
\hline $\mathrm{df}_{\text {model }}$ & 5 & 5 & 5 & 5 & 5 & - & - \\
\hline $\mathrm{df}_{\text {error }}$ & 24 & 22 & 22 & 22 & 22 & - & - \\
\hline
\end{tabular}

${ }^{1}$ Means followed by the same letter in columns do not statistically differ between each other according to Tukey test, at 5\% probability. ${ }^{2}$ Mortality (\%) calculated by E\% = 100\% - (100\%-M\%) (modified from Overmeer \& Van Zon, 1985). Where E = total effect (\%); M\% $=$ Mortality corrected by control (Abbott, 1925$) .{ }^{3} \mathrm{C}=$ Classes: class $1=$ harmless $(\mathrm{E}<30 \%)$; class $2=$ slighgtly harmful $(30 \% \leq \mathrm{E}<80 \%)$; class $3=$ moderately harmful $(80 \% \leq \mathrm{E}<99 \%)$; and class $4=$ harmful $(\mathrm{E} \geq 99 \%)$. 
and an immediate reduction of the internal calcium occurs at the same time, preventing the normal muscular contractions of the insect and causing its death by paralysis (Ebbinghaus-Kintscher et al., 2007; United, 2008). Acceptable safety to incrop non-target organisms has been demonstrated by these products. Tohnishi et al. (2005) have reported that flubendiamide was not toxic to some natural enemies within order Coleoptera, similar to what was reported by Fonseca et al. (2012) in a field study with the predator Calosoma granulatum (Coleoptera: Carabidae) and by Reis et al. (2011) in selectivity tests for predator mites with chlorantraniliprole. Comparative studies have demonstrated that differential selectivity of chlorantraniliprole for insect receptors is more than 350-fold that for mammalian receptors.

By acting chiefly by ingestion and possessing little contact activity, the insecticides of diamides group show themselves fairly selective, once they will act more specifically on phytophagous insects, mainly those insects within order Lepidoptera. In addition, these insecticides are considered safe to non-target organisms, chiefly mammals and natural enemies that do not feed on plants (Lahm et al., 2009). Selectivity of insecticides from group of diamides were ratified with result herein achieved, since both tested insecticides of this group were classified as harmless (class 1) to $D$. lineare. Therefore, considering these selectivity characteristics, it can be concluded that these products can be used safely in the Corn-IPM when necessary, allowing compatibility of chemical control with the preservation of the natural biological control.

The combination of chlorantraniliprole + lambda-cyhalothrin, however, was classified as slightly harmful (class 2). This probably happened due to lower selectivity of this combination in relation to treatment with chlorantraniliprole tested alone, once it has been mixed with a product belonging to the pyrethroid group that usually are less selective to natural enemies (Carmo et al., 2010) (Table 1). As it can be noticed within this study, when these molecules were tested separately, the insecticide chlorantraniliprole was harmless to the predator $D$. lineare, while the insecticide lambda-cyhalothrin was moderately harmful. Therefore, the association of two mechanisms of action differentiated, may turn products more efficient against pest-insects; but can also expand their action mode, thus making them less selective to the natural enemies.

The preservation of the biological natural control agents, as the earwigs for example, is frequently limited by incompatibility between pesticides and natural enemies survival. Thus, selectivity of products used in the management of corn pests is of great value, and the use of more modern molecules and/or more selective molecules as flubendiamide and chlorantraniliprole should be encouraged. Therefore, it is important emphasizing that for the remaining tested pesticides (lambdacyhalothrin, chlorantraniliprole + lambdacyhalothrin, and chlorpyrifos), the harmfulness obtained in the laboratory should be thereafter assessed under greenhouse and field conditions, following the standards of selectivity tests established by the IOBC/WPRS, in order to obtain further information in relation to their persistence and toxicity under field condition. On the other hand, however, the harmless (class 1) products did not need to be further tested and can be hold selective to $D$. lineare adults. 


\section{Conclusions}

- The insecticides flubendiamide and chlorantraniliprole are harmless to predator $D$. lineare, being suitable to be used in Corn Integrated Pest Management programs;

- The compounds associating the insecticides chlorantraniliprole + lambda-cyhalothrin is slightly harmful to the predator $D$. lineare; and for this reason should be used with caution in Corn Integrated Pest Management programs;

- The insecticides lambda-cyhalothrin and chlorpyrifos are not selective to the predator $D$. lineare and their use within the Corn-IPM should be avoided and, whenever possible, replaced by other pesticides, more selective to natural enemies.

\section{References}

ABBOTT, W. S. A method of computing the effectiveness of insecticide. Journal of Economic Entomology, Colllege Park, v. 18, p. 265-267, 1925.

BACCI, L.; PICANÇO, M. C.; GUSMÃO, M. R.; CRESPO, A. L. B.; PEREIRA, E. J. G. Seletividade de Inseticidas a Brevicoryne brassicae (L.) (Hemiptera: Aphididae) e ao Predador Doru luteipes (Scudder) (Dermaptera: Forficulidae). Neotropical Entomology, Londrina, v. 30, p. 707-713, 2001.

BUENO A. F.; FREITAS, S. Effect of the insecticides abamectin and lufenuron on eggs and larvae of Chrysoperla externa under laboratory conditions. BioControl, Dordrecht, v. 49, p. 277-283, 2004.

BUENO, A. F.; BUENO, R. C. O. F.; PARRA, J. R. P; VIEIRA, S. S. Effects of pesticides used in soybean crops to the egg parasitoid Trichogramma pretiosum. Ciência Rural, Santa Maria, v. 38, p. 1495-1503, 2008.

BURR, I. W.; FOSTER, L. A. A test for equality of variances. West Lafayette: University of Purdue, p. 26, 1972.

CAMPOS, M. R.; PICANÇO, M. C.; MARTINS, J. C.; TOMAZ, A. C.; GUEDES, R. C. N. Insecticide selectivity and behavioral response of the earwig Doru luteipes. Crop Protection, Surrey, v. 30, p. 1535-1540, 2011.

CARMO, E. L.; BUENO, A. F.; BUENO, R. C. O. F. Pesticide selectivity for the insect egg parasitoid Telenomus remus. BioControl, Dordrecht, v. 55, p. 455-464, 2010.

CARVAlHO, G. A.; PARRA, J. R. P.; BAPTISTA, G. C. Ação residual de alguns inseticidas pulverizados em plantas de tomateiro sobre duas linhagens de Trichogramma pretiosum Riley, 1879 (Hymenoptera: Trichogrammatidae) em casa-de-vegetação. Ciência e Agrotecnologia, Lavras, v. 23, p. 770-775, 1999.

CONAB. Safras-grãos. Disponível em: $<$ http:// www.conab.gov.br/OlalaCMS/uploads/ arquivos/12_10_17_16_09_58_boletim_ graos_-julho_2012.pdf> Acesso em: 27 jul. 2012.

COSTA, N. P.; OLIVEIRA, D. H.; BRITO, C. H.; SILVA, A. B. Influência do nim na biologia do predador Euborellia annulipes e estudo de parâmetros para sua criação massal. Revista de Biologia e Ciências da Terra, Campina Grande, v. 7, 2007.

CRUZ, I. A Lagarta do cartucho na cultura do milho. Sete Lagoas EMBRAPA-CNPMS, 1995. 45 p. (EMBRAPA-CNPMS.Circular Técnica, 21)

EBBINGHAUS-KINTSCHER, U.; LÜMMEN，P.; 
RAMING, K.; MASAKI, T.; YASOKAWA, N. Flubendiamide, the first insecticide with a novel mode of action on insect ryanodine receptors. Pflanzenschutz-Nachrichten Bayer, Leverkusen, v. 60, p. 117-140, 2007

UNITED STATES. Environmental Protection Agency. Pesticide Fact Sheet: Chlorantraniliprole. [s.l.], 2008. $77 \mathrm{p}$.

FERREIRA, A. J.; CARVALHO, G. A.; BOTTON, M.; LASMAR, O. Seletividade de inseticidas usados na cultura da macieira a duas populações de Chrysoperla externa (Hagen, 1861) (Neuropetra: Chrysopidae). Ciência Rural, Santa Maria, v. 36, p. 378-384, 2006.

FIGUEIREDO, M. L. C.; MARTINS-DIAS, A. M. P.; CRUZ, I. Relação entre a lagarta-do-cartucho e seus agentes de controle biológico natural na produção de milho. Pesquisa Agropecuária Brasileira, Brasília, DF, v. 41, p. 1693-1698, 2006.

FONSECA, P. R. B.; MOTA, T. A.; KASSAB, S. O.; FERNANDES, M. G. Seletividade de inseticidas utilizados no controle da Spodoptera frugiperda (J. E. Smith, 1797) nos inimigos naturais epigéicos na cultura do milheto. Caatinga, Mossoró, v. 25, p. 14-19, 2012.

GUEDES, R. N. C.; LIMA, J. O. G.; ZANUNCIO, J. C. Seletividade dos inseticidas deltametrina, fenvaleratoefenitrotiomparaPodisusconnexivus Bergroth, 1891 (Heteroptera: Pentatomidae). Anais da Sociedade Entomológica do Brasil. Jaboticabal, v. 21, p. 339-346, 1992.

HASSAN, S. A.; HALSALL, N.; GRAY, A. P.; KUEHNER, C.; MOLL, M.; BAKKER, F. M.; ROEMBKE, J.; YOUSEF, A.; NASR, F.; ABDELGADER, H. Laboratory method to evaluate the side effects of plant protection products on Trichogramma cacoeciae Marchal (Hymenoptera: Trichogrammatidae). In: CANDOLFI, M. P.; BLUMEL, R.; FORSTER, R.; BAKKER, F. M.; GRIMM, C.; HASSAN, S. A.; HEIMBACH, U.; MEAD-BRIGGS, M. A.; REBER, B.; SCHMUCK, R.; VOGT, H. (Ed.). Guidelines to evaluate side-effects of plant protection products to non-target arthropods. Gent: International Organization for Biological and Integrated Control of Noxious Animals and Plants, West Palaearctic Regional Section (IOBC/WPRS), 2000. p. 107-119.

KOMEZA, N.; FOUILLET, P.; BOULÉTREAU, M.; DELPUECH, J. M. Modification, by insecticide chlorpyrifos, of the behavioral responses to kairomones of a parasitoid wasp, Leptopilina boulardi. Archives of Environmental Contamination and Toxicology, New York, v. 41, p. 436-442, 2001.

LAHM, G. P.; CORDOVA, D.; BARRY, J. D. New and selective ryanodine receptor activators for insect control. Bioorganic \& Medicinal Chemistry, Oxford, v. 17, p. 4127-4133, 2009.

MANZONI, C. G.; GRÜTZMACHER, A. D.; GIOLO, F. P.; HÄRTER, W. DA R.; CASTILHOS, R. V.; PASCHOAL, M. D. F. Seletividade de Agroquímicos utilizados na produção integrada de maçã aos parasitóides Trichogramma pretiosum Riley e Trichogramma atopovirilia Oatan \& Platner (Hymenoptera: Trichogrammatidae). Bioassay, Londrina, v.2, p.1-11, 2007.

MOHAGHEGH, J.; DE CLERCQ, P.; TIRRY, L. Toxicity of selected insecticides to the spined soldier bug, Podisus maculiventris (Heteroptera: Pentatomidae). Biocontrol Science and Technology, Oxford, v. 10, p. 33-40, 2000. 
PICANÇO, M. C.; MOURA, M. F.;. MIRANDA, M. M. M; GONTIJO, L. M.; FERNANDES, F. L. Seletividade de inseticidas a Doru luteipes (Scudder, 1876) (Dermaptera: Forficulidae) e Cotesia sp. (Hymenoptera: Braconidae) inimigos naturais de Ascia monuste orseis (Godart, 1818) (Lepdoptera: Pieridae). Ciência Rural, Santa Maria, v. 33, p. 183-188, 2003.

REDOAN, A. C. M.; CARVALHO, G. A.; CRUZ, I.; FIGUEIREDO, M. L. C.; SILVA, R. B. Seletividade de inseticidas utilizados no controle de Spodoptera frugiperda (J. E. Smith) (Lepidoptera: Noctuidae) para ovos e ninfas de Doru luteipes (Scudder) (Dermaptera: Forficulidae). Revista Brasileira de Milho e Sorgo, Sete Lagoas, v. 11, p. 25-34, 2012.

REIS, P. R.; FRANCO, R. A.; SILVA, F. M. A. Selectivity of rynaxypyr for three species of phytoseiid mites relevant to coffee in Brazil. Coffee Science, Lavras, v. 6, p. 212-216, 2011.

SAS INSTITUTE. SAS user'sguide: statistics. 6. ed. Cary, 2001. $201 \mathrm{p}$.

SAUPHANOR, B.; BLAISINGER, P.; SUREAU, F. Methode de laboratoirepour evaluer L'effet des pesticides sur Forficula auricularia L. (Dermaptera: Forficulidae). In: HASSAN, S. A. (Ed). Guidelines for testing the effects of pesticides on beneficial organisms:
Description of test methods. [S.1.]: OILB/SROP, 1992. p. 117-121. (Bulletin OILB/SROP, 15/3).

SHAPIRO, S. S.; WILK, M. B. An analysis of variance test for normality. Biometrika, London, v. 52, p. 591-611, 1965.

TOHNISHI, $M$. et al. Flubendiamide, a novel insecticide highly active against lepidopterous insect pests. Journal of Pesticide Science, Tokyo, v. 30, n. 4, p. 354-360, 2005.

YU, S. J. Biochemical defense capacity in the spined soldier bug (Podisus maculiventris) and its lepidopterous prey. Pesticide Biochemistry and Physiology, New York, v. 28, p. 216-223, 1987.

ZOTTI, M. J.; GRÜTZMACHER, A. D.; GRÜTZMACHER, D. D.; CASTILHOS, R. V.; MARTINS, J. F. S. Seletividade de inseticidas utilizados na cultura do milho para ovos e ninfas do predador Doru lineare (Eschscholts, 1822) (Dermaptera: Forficulidae). Arquivos do Instituto Biológico, São Paulo, v. 77, p. 111-118, 2010a.

ZOTTI, M. J.; GRÜTZMACHER, A. D.; GRÜTZMACHER, D. D.; DALMAZZO, G. O.; MARTINS, J. F. S. Seletividade de inseticidas usados na cultura do milho para adultos de Doru lineare (Eschscholtz, 1822) (Dermaptera: Forficulidae). Arquivos do Instituto Biológico, Sao Paulo, v. 77, p. 291-299, 2010b. 